\title{
Adenosarcoma pT1b TNM Finding v7
}

National Cancer Institute

\section{Source}

National Cancer Institute. Adenosarcoma pT 1b TNM Finding v7. NCI Thesaurus. Code C89613.

Tumor invades to less than half of the myometrium. (from AJCC 7th Ed.) 